\title{
Physicochemical Characteristics of Landfill Leachate From Simpang Renggam Landfill Site, Johor, Malaysia
}

\author{
Amir Detho ${ }^{1,2, *}$, Zawawi Daud², Saleem Raza Samoํ, Zohaib Khan ${ }^{3}$, Danish Ali Memon ${ }^{4}$, Halizah \\ Awang 5
}

${ }^{1}$ Department of Energy and Environment Engineering, QUEST, Nawabshah, Sindh, Pakistan

${ }^{2}$ Faculty of Civil Engineering and Built Environment, Universiti Tun Hussein Onn Malaysia

${ }^{3}$ Faculty of Mechanical Manufacturing Engineering, Universiti Tun Hussein Onn Malaysia

${ }^{4}$ Mehran University of Engineering and Technology, SZAB Campus, Khairpur Mirs

${ }^{5}$ Faculty of Technical and Vocational Education, Universiti Tun Hussein Onn Malaysia, Batu Pahat, Malaysia

${ }^{*}$ Corresponding author: amirdetho@gmail.com

\section{Abstract}

The worldwide increasing amount of municipal solid waste causes a major problem in managing waste as well as requires an effective solution to manage the waste generation. In Malaysia, landfilling is the main alternative technique for managing solid waste. In the same way, the main advantage of having a landfill is that it is easy to operate and comparatively lower in cost. Thus, in Malaysia, total 296 municipal solid waste landfills are open to overcome this issue. Drawbacks of landfilling can includes; i) generation of noxious gases, ii) leachate wastewater contamination of both ground and surface water, iii) problems such as odor, noise, and dust, iv) attraction of disease vectors and, v) the requirement for considerable land area. This present research study focuses on the characterization of Simpang Renggam Landfill (SRLS) Site such as its organic constitutes $(\mathrm{mg} / \mathrm{L})$, Ammoniacal Nitrogen $(\mathrm{mg} / \mathrm{L})$, SS $(\mathrm{mg} / \mathrm{L})$, BOD5/COD, BOD5 $(\mathrm{mg} / \mathrm{L})$, and $\mathrm{pH}$. All the analyzed results were compared with the past researchers' researches and also were compared with Malaysian Environmental Quality Act 1974. From the results, it is concluded that the Simpang Renggam Landfill Site was characterized old (stabilized) landfill leachate wastewater with BOD5/COD $>0.1$. For the SRL site, it is recommended that physical-chemical method is better fitted for the leachate wastewater treatment and the aerated lagoon technique does not support the treatment of aging leachate.

Keywords_-Leachate characterization, Simpang Renggam Landfill Site, Organic constitutes, Ammonia Nitrogen, SS, pH.

\section{Introduction}

$\mathrm{T}$ HE complexities of solid waste management increase day by day. Many countries are struggling to implement a cost-effective and environmentally sustainable solution. The increasing generation rate of solid waste has to make it particularly necessary for officials in charge of solid waste management to establish strategies for the safe and cost-effective management of waste. The management of solid waste usually involves recycling, composting recovery, and combustion with or without energy recovery, as illustrated in Figure 1. The alternative approach to handling waste is landfill

ISSN: 2523-0379 (Online), ISSN: 1605-8607 (Print)

DOI: 10.52584/QRJ.1802.13

This is an open access article published by Quaid-e-Awam University of Engineering Science $\&$ Technology, Nawabshah, Pakistan under CC BY 4.0 International License. disposal [1-3].

The growing amount of solid waste contributes to a negative impact on the environment as well as the main cause of pollution including soil, air, and water bodies [4]. Municipal Solid Waste (MSW) is generated from different sources including residential waste, commercial waste, institutional waste, and industrial waste sources. However, it does not include such things as construction wastes, auto mobile bodies, municipal sludges, combustion ashes, and industrial process wastes even though these wastes might also be disposed of in a municipal waste landfill or incinerator [5-7].

According to sources, few common techniques are used as an alternative to the management of solid waste disposal, such as open dumping, incinerator, compaction, milling, gridding, drainage discharging, 


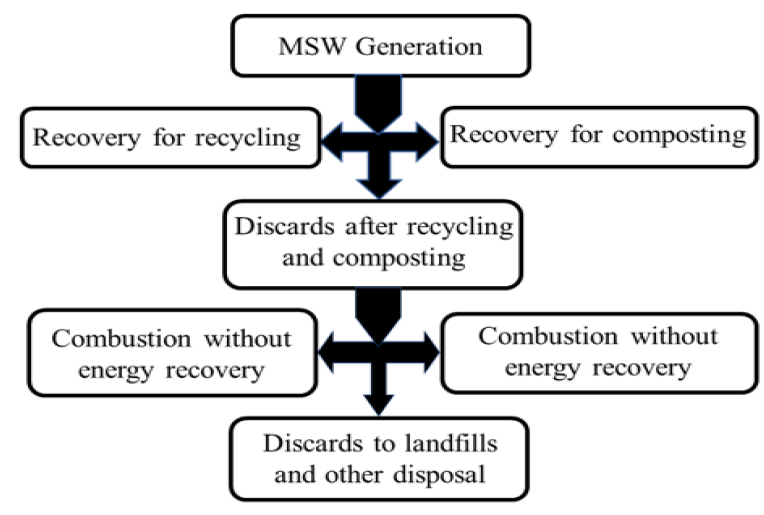

Fig. 1: Solid waste management [1]

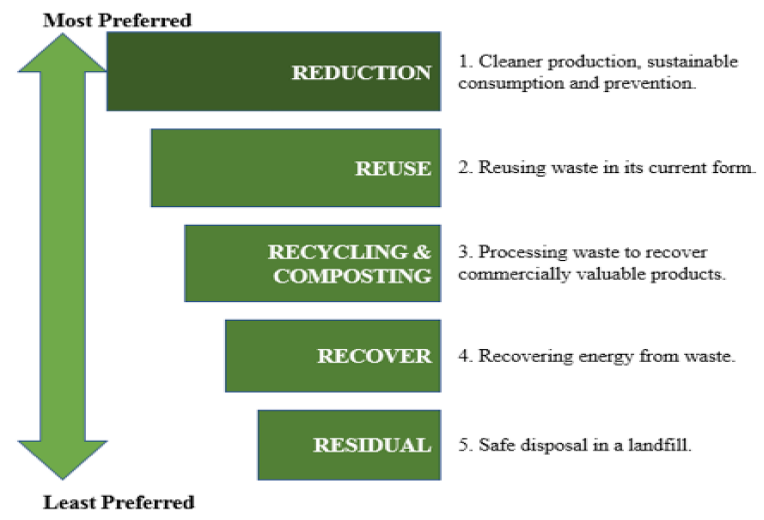

Fig. 2: Current practices of MSW management

sanitary land-filling, dumping and composting, reducing and anaerobic digesting [8]. Among all these methods, landfilling is the most widely used approach for managing the dumping of solid waste in many parts of the world. Other than that, disposal of urban and industrial wastes is the most effective in low cost, economical, and environmentally appropriate techniques [9-12].

Leachate wastewater typically contains a higher concentration of organic and inorganic matters, heavy metals, and chlorinated organics [10]. Landfill leachate usually contains a high load of the dissolved contaminant directly discharged into the environment which may contaminate soil, subsoil and water bodies as well as poses serious threats to the environment, human health, and ecosystems. Therefore, pollutant reduction from leachate treatment has become a significant concerned over the last few decades [9]. There are a number of factors which affect characterization of leachate wastewater including the age of landfill site, hydrogeological condition, seasonal variation, weather condition, water flowing rate through the wastes, leachate temperatures, $\mathrm{pH}$, water contents, condition and operation of landfill facilities [13-16].

According to the age of landfill, landfill leachate wastewater can be categorized into three groups: i) young, ii) medium and, iii) old. The characteristics of leachate wastewater versus the age of landfill are summarized in Table 1 [17-18].According to leachate characteristics, it can be easily categorized and identified as young leachate or old (stabilized) leachate. Old landfill leachate wastewater is defined as a low biodegradable ratio value $(<0.1)$ which is difficult to proceed with biological treatment methodology. A change in the biodegradable ratio in leachate wastewater describes the quality of various forms of leachate wastewater that have been described based on the landfill age and decomposition of landfill leachate wastewater. Generally, biodegradable ratio of young leachate include less than 1 year old, intermediate leachate (1-5 years) and old (stabilized) leachate ( $>5$ years) were reported as $0.5-1.0,0.1-0.55$, and $<0.1$, respectively [19].

In this paper, six parameters such as Chemical Oxygen Demand (COD), Ammonia Nitrogen (NH3N), Power of Hydrogen (pH), Suspended Solid (S.S), Biologycal Oxygen Demand (BOD), and Bio Degradability Ratio (BOD5/COD) were investigated and analyzed from the SRL site. The analyzed results were compared both with the Malaysia Environmental Quality Act (MEQA 1974) and past research. The work presented in this paper provides the current data of leachate characterization properties from the SRL site, Johore, Malaysia. Other researchers can use this data to better understand the leachate characterization properties and propose new ideas or solutions to improve the efficacy of leachate wastewater treatment. Table 1 illustrates the leachate wastewater properties versus age of the landfill [20].

\section{Theoretical Approach to Minimize Waste}

Figure 2 shows the current practices of MSW handling, which indicates a greater part of MSW directly disposed off into the landfills, and less importance has been given on reusing, recycling and composting. Though, this practice creates environmental issues in terms of leachate generation from the landfill and pollute the soil and under-ground water. The present practices are not environmentally acceptable, but are extensively used due to the unavailable of advanced technology and skilled professional. It is very hard for the concerned authorities to switch from one method to a more advanced technology [21]. 


\begin{tabular}{|l|l|l|l|}
\hline Parameters & Leachate Type & & \\
\hline Landfill age (years) & $<5$ (young) & $5-10$ (medium) & $>10$ (old) \\
\hline pH & $<6.5$ & $6.5-7.5$ & $>7.5$ \\
\hline COD (mg/L) & $>10,000$ & $4000-10,000$ & $<4000$ \\
\hline BOD5/ COD & $0.5-1.0$ & $0.1-0.5$ & $<0.1$ \\
\hline HAmmonia nitrogen (mg/L) & $<400$ & N. A & $>400$ \\
\hline TOC/COD & $<0.3$ & $0.3-0.5$ & $>0.5$ \\
\hline Heavy metal (mg/L) & Low to medium & Low & Low \\
\hline Biodegradability & Important & Medium & Low \\
\hline Organic Compounds & $80 \%$ volatile fatty acid & $5 \%-30 \%$ VFA + Humic and & Humic and fulvic acid \\
\hline
\end{tabular}

TABLE 1: Landfill leachate characteristics at different land-fill ages [20]

\subsection{Environmental Issue}

In urban areas, one of the major issues of MSW in the perspective of environment is the collection, management, and disposal. Lack of mismanagement of solid waste jumps to environmental and social issues. This includes contamination of air water, soil, and aesthetics. Such environmental issues are related to human health disorder because of increasing amount of greenhouse gases emission [22-23].

\subsection{Landfilling}

A landfill is a well-known technique for the disposal of municipal solid waste. Thus, it covers a huge area and environmental issues regarding leachate and emits harmful greenhouse emissions (GHG) such as $\mathrm{CH} 4$, $\mathrm{N} 2 \mathrm{O}$, and $\mathrm{CO} 2$. The leachate generated by landfills can pollute underground water and soil. However, leachate also pollutes the surrounding environment, living spaces, commerce, and recreational areas [24].

\subsection{Air Emission}

During the waste disposal process, large quantities of landfill gasses will be released in the atmosphere at the landfill site. These landfill gases consist mainly of methane and carbon dioxide. With its high methane emission, the landfill was considered one of the major sources of methane pollution at around $50 \%$ to $60 \%$. According to a study, the release of $1 \mathrm{~kg}$ of methane will result in an equal contribution of $35 \mathrm{~kg}$ of $\mathrm{CO} 2$ to global warming over a 20 -year period. This greenhouse impact would result in changes and disrupt the ecosystem's equilibrium such as rising global sea levels and extreme weather conditions such as heavy flooding and severe droughts. In order to control the release of methane gas in atmosphere, a proper gas venting and collection system is necessary [25].Other than methane and $\mathrm{CO} 2$, landfill gasses consist of certain trace levels of carcinogenic-organic chemicals such as vinly chloride, toluence, and benzene. If they are above acceptable limits, these carcinogenic gasses will have a harmful effect on human health [26].

\subsection{Public Health}

Uncontrolled dumping at the dumpsite poses a significant threat not only to site staff but also to those living near the disposal facilities and those who derive their income from these sources. Local authorities often get complaints from public about bad odor from open dumpsites and landfills without regular soil cover. But the effect is more than just stingy taste, it puts public health at risk. A known carcinogen is one of the components found in the volatile organic compound (VOC), benzene, and exposure to $1 \mu \mathrm{g} / \mathrm{m}^{3}$ creates a lifetime risk of $4 \times 10^{-6}$ for leukaemia [27] (WHO, 1987).

A sample household study of conducted field research reports around $23 \%$ out of 456 householders samples a minimum one-case of gastrointestinal disease recorded over a period of earlier one month and an additional $18 \%$ of a minimum of one case of typhoid, cholera or jaundice over a period of one year due to the reuse of untreated waste in agricultural [28]. With proper maintenance of the sanitary landfill, especially on a daily basis, it is possible to prevent vector breeding and housing thus avoid epidemics such as dengue fever and plague.

\section{Materials \& Methods}

Following sections describe the materials and methods used in this study.

\subsection{Site Location}

The leachate wastewater sample was collected manually from SRL site which is located at latitude 10 53'41.64 N and longitude 1030 22'34.68 E Kluang district, Johore, Malaysia. A total area of the SRL site covers approximately 14.82 acres and for the process of leachate wastewater treatment, aerated lagoon system is used. The landfill was managed for many years. The SRL site is now more than 12 years old. The initial size of the area was only 6 hectares making it impossible to contain the high volume of waste being 


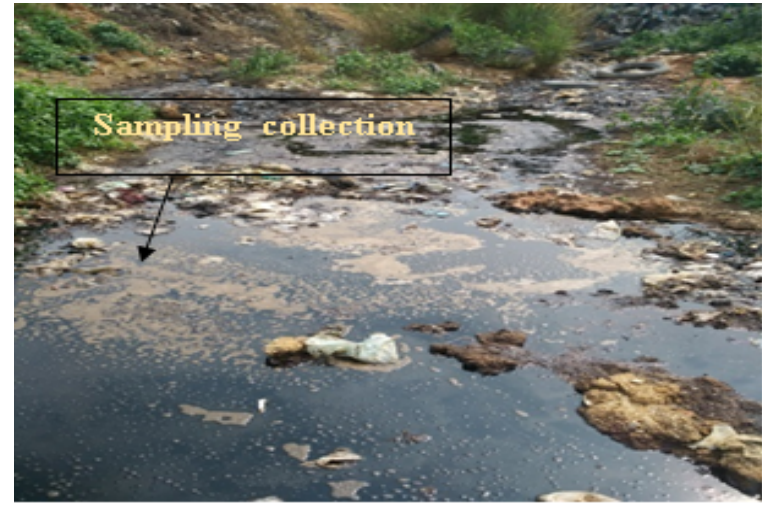

Fig. 3: Simpang Renggam Landfill Site

transported; therefore, the government established a new sanitary landfill beside the existing one to manage the waste brought from the surrounding districts. The SRL site receives about 250 tons of solid waste per day covering three regions (i.e. Simpang Ringgam region, Batu Pahat region and Kluang district). Figure 3 shows the SRL site.

\subsection{Leachate Wastewater Sampling}

A fresh sample of leachate wastewater was collected manually from the SRL site in a 30-L clean (HDPE) high-density polyethylene container. The collected samples were transported directly to the wastewater laboratory and kept in a cold storage room at room temperature at Universiti Tun Hussein Onn Malaysia (UTHM) to prevent further chemical changes that occur in their initial characterization. The experimental procedure and analysis were done according to the method of the American Public Health Association (APHA 2012) [31]. Our study investigated six parameters such as organic constitutes, Ammoniacal Nitrogen, SS, pH, BOD, and BOD5/COD which were determined and analyzed from the Simpang Renggam landfill site.

\section{Results \& Discussion}

Many previous research studies describe the variation in leachate quality from different landfills [32]. Leachate characteristics utilized in this study are shown in Table 2. The leachate has a high volume of NH3-N and COD as shown in Table 3. The average value of COD and BOD5 is $1829 \mathrm{mg} / \mathrm{L}$ and $163 \mathrm{mg} / \mathrm{L}$, respectively. A fresh sample of leachate wastewater has a biodegradability ratio (BOD5/COD) of $0.07-$ 0.08 with an average of 0.07 , as shown in Table 2 . The results show that the value of COD and BOD5 demonstrate that the leachate is clearly stabilized.
Stabilized leachate has a high concentration of COD $(<3000 \mathrm{mg} / \mathrm{L})$ and NH3-N (>400 mg/L) but low concentration of BOD5/COD [33]. The $\mathrm{pH}$ concentration of leachate has a range of $7.65-8.27$ with an average of 7.96 and it increases gradually with time [34]. A previous study describes that the concentration of $\mathrm{pH}$ of a stabilized leachate is higher than 7.5 [35].

\subsection{Chemical Oxygen Demand (COD)}

In our study, the value of COD was obtained from Simpang Renggam landfill Site (SRLS) which varies at an average of $1829 \mathrm{mg} / \mathrm{L}$. According to previous studies, the authors [36] conducted a research at SRLS in 2013. The value of COD was recorded between 13,166 and $13,500 \mathrm{mg} / \mathrm{L}$. In another study, the authors [37] conducted a research at SRLS in 2015 in which the value of COD was recorded between 9839 and 15680 $\mathrm{mg} / \mathrm{L}$. The results show that from 2013 to 2017, the value of COD decreases due to the ages of landfill ( $>$ 10 years).

\subsection{Biological Oxygen Demand (BOD)}

The Biological Oxygen Demand value examined in the present research study was $163 \mathrm{mg} / \mathrm{L}$ to compare with past research works on Biological Oxygen Demand (BOD). The authors in [37] show that the average recorded value was high $3183 \mathrm{mg} / \mathrm{L}$. On the other hand, the authors in [38] state that the BOD value for mature landfills varies from $100 \mathrm{mg} / \mathrm{L}$ to $200 \mathrm{mg} / \mathrm{L}$. The BOD value is obtained from SRLS and is recorded within the range of $100 \mathrm{mg} / \mathrm{L}$ to $200 \mathrm{mg} / \mathrm{L}$. Based on the obtained results, the landfill is considered as mature landfill. By comparing the results with MEQA (1974), it exceeds more than $50 \mathrm{mg} / \mathrm{L}$ and is considered a better treatment to reduce the BOD concentration.

\subsection{Suspended Solid (SS)}

A 2013 study [36] records the value of SS to be between $270 \mathrm{mg} / \mathrm{L}$ to $1200 \mathrm{mg} / \mathrm{L}$. On the other hand another study reports it to be between $1200 \mathrm{mg} / \mathrm{L}$ to 1240 $\mathrm{mg} / \mathrm{L}$ [37]. In this study, the SS value is recorded from Simpang Renggam landfill Site (SRLS) which varies at an average of $341 \mathrm{mg} / \mathrm{L}$. According to the results, the value of SS increases. By comparing the value with MEQA (1974), suspended solid exceeds more than the allowable limits of $50 \mathrm{mg} / \mathrm{L}$.

\subsection{Power of Hydrogen $(\mathrm{pH})$}

The value of $\mathrm{pH}$ obtained from Simpang Renggam land-fill Site (SRLS) varies at an average of 7.68 to 


\begin{tabular}{|l|l|l|l|l|l|}
\hline Parameters & Units & Minimum & Maximum & Average & MEQA (1974) \\
\hline COD & $\mathrm{mg} / \mathrm{L}$ & 1595 & 1829 & 1712 & 400 \\
\hline Ammonia & $\mathrm{mg} / \mathrm{L}$ & 404.07 & 406.68 & 405.37 & 5 \\
\hline pH & - & 7.65 & 8.27 & 7.96 & $6.0-9.0$ \\
\hline SS & $\mathrm{mg} / \mathrm{L}$ & 316 & 367 & 341.5 & 50 \\
\hline BOD5/COD & - & 0.07 & 0.08 & 0.07 & - \\
\hline BOD5 & $\mathrm{mg} / \mathrm{L}$ & 140 & 163 & 138.66 & 20 \\
\hline
\end{tabular}

TABLE 2: CHARACTERISTIC OF THE COLLECTED LEACHATE FROM SRL SITE

8.27. The value of $\mathrm{pH}$ increased because of the age factor of landfill and gas production [38]. Past results were recorded in year 2013, where the obtained recorded value of $\mathrm{pH}$ was from 8.31 to 8.47 [36]. Leachate is classified as old with $p H>7.5$ [20]. By comparing the value with MEQA (1974), the obtained $\mathrm{pH}$ value ranging from 6.0 to 9.0 were found to be acceptable. Therefore, leachate can be discharged without further $\mathrm{pH}$ adjustment.

\subsection{Ammonia Nitrogen (NH3-N)}

From the result obtained from Simpang Renggam Land-fill Site (SRLS) which varies at an average of $406.68 \mathrm{mg} / \mathrm{L}$. A study was conducted [39] which had found ammonia concentration value between 200 $\mathrm{mg} / \mathrm{L}$ to $1000 \mathrm{mg} / \mathrm{L}$. It does not have an adverse effect on anaerobic processes. Therefore, the biological treatment is not recommended for SRL sites from the previous study reported by the authors in [36], which shows a higher concentration of ammoniacal nitrogen in 2013 that was between $755 \mathrm{mg} / \mathrm{L}$ to $2670 \mathrm{mg} / \mathrm{L}$. The concentration of ammoniacal nitrogen reduction is due to the lack of organic matter [39]. By comparing the value with MEQA (1974), the obtained value of ammonia is found to be higher than the acceptable limits $(5 \mathrm{mmg} / \mathrm{L})$. The concentration of ammoniacal nitrogen can be decreased in several processes, such as physicochemical treatment, to reach standard discharge limits.

\subsection{Biodegradability Ratio (BOD5/COD)}

The biodegradability ratio (BOD5/COD) is used to determine the age of landfill [39]. According to the characteristics of biodegradability of Simpang Renggam Landfill Site (SRLS), it varies at an average range of 0.08. From the obtained results, the leachate is classified as old (stabilized) leachate wastewater with BOD5/COD value $<0.1$. Thus, the concentration of BOD5/COD decreases throughout the age increment of landfill [40]. The characterization of biodegradable ratio tends to be taken as the best alternative to determine biological and chemical decomposition occurred at SRLS.

\section{Conclusion}

Leachate characteristics of the SRL Site were examined and analyzed. In this research study, six parameters were examined and analyzed in its composition. Among these parameters, COD and BOD show the age of landfill significantly affects the leachate characteristics composition of SRL site. It is concluded that from the year 2013, the leachate characteristics changes due to various factors. Leachate wastewater from the SRL site contains a lower concentration of organic and inorganic constituents based on a biodegradable ratio. SRL site categorizes as old (stabilized) leachate. The upgrade treatment method must be considered due to a lack of change in the composition of leachate. Therefore, for further works, it is suggested to be taken into account to upgrade treatment methods that need to be considered for leachate wastewater treatment due to the variation of leachate composition.

\section{Acknowledgement}

The authors would like to express thanks to Ministry of Higher Education Malaysia, Universiti Tun Hussein Onn Malaysia under Research Fund E15501, Research Management Centre (RMC) UTHM and Quaid-e-Awam University of Engineering, Science and Technology, Nawabshah, Sindh, Pakistan

\section{References}

[1] G. M. Masters, W. P. Ela, Introduction to environmental engineering and science (No. 60457). Englewood Cliffs, NJ: Prentice Hall, 2008.

[2] A. Nandan, N. A. Siddiqui and P. Kumar, "Assessment of environmental and ergonomic hazard associated to printing and photocopying: a review", Environmental geochemistry and health, Vol. 41, pp. 1187-1211, 2019.

[3] S. Khamparia, D. Jaspal and A. Malviya, 10 Green and Eco-Friendly Materials for the Removal of Phosphorus from Wastewater. Life Cycle Assessment of Wastewater Treatment 199-219 (2018).

[4] D. Moeler, Environmental Health (3rded.). Cambridge, MA. Harvard University Press (2005).

[5] S.H. Fauziah, P. Agamuthu, "Sustainable Household Organic Waste Management via Vermicomposting", Malaysian Journal of Science, Vol. 28, No.2, pp. 135-142, 2009. 
[6] H.B. Ismail, A.C. Hassan, M.H. Jamal, J. Martin, M.Z.M. Salleh, W.S.W. Chik and N.A.U. Yusof, "Potential revenue from solid waste recycling practices in faculty of civil engineering UiTM Johor, Pasir Gudang campus", Journal of Fundamental and Ap-plied Sciences, Vol. 10, pp. 2540-2550, 2018.

[7] M. A. Khattak, L. J. Keat, K. A. Bapujee, T. X. Hui, A. Syafiq, A. D. A. R Othman and S. Kazi, "Global Energy Security and Ma-laysian Perspective: A Review", Progress in Energy and Environ-ment, Vol. 6, pp. 1-18, 2018.

[8] M. Zin, N. Shaylinda, H. Abdul Aziz, M. N. Adlan and A. Ar-iffin, "Characterization of leachate at Matang Landfill site, Pe-rak, Malaysia", Academic Journal of Science, Vol. 1, No. 2, pp. 317-322, 2012.

[9] Z. Daud, N. Nasir, A.A. Ab. Latiff, M. B. Ridzuan and H. Awang, "Treatment of biodiesel wastewater by coagulationflocculation process using polyaluminium chloride (PAC) and polyelectrolyte anionic", ARPN Journal of Engineering and Applied Sciences, Vol. 11, No. 20, pp. 11855-11859, 2016.

[10] M. J. Bashir, H. A. Aziz, M. S. Yusoff and S. Q. Aziz, "Color and chemical oxygen demand removal from mature semi-aerobic landfill leachate using anion-exchange resin: An equilibrium and kinetic study", Environmental engineering science, Vol. 29, No. 5, pp. 297-305, 2012.

[11] Z. Daud, H. A. Aziz, M. N. Adlan and Y. T Hung, "Application of combined filtration and coagulation for semi-aerobic leachate treatment", International Journal of Environment and Waste Man-agement, Vol. 4, No. 3-4, pp. 457-469, 2009.

[12] Z. Daud, M. H. Abubakar, A. A. Kadir, H. Awang, A. A. Halim and A. Marto, "Optimization of leachate treatment with granu-lar biomedia: Feldspar and Zeolite", Indian Journal of Science and Technology, Vol. 9, No. 37, pp. 1-5, 2016.

[13] Z. Daud, M. H. Abubakar, A. A. Kadir, A. A. A. Latiff, H. Awang, A. A. Halim and A. Marto, "Adsorption studies of leachate on cockle shells", International Journal of GEOMATE, Vol. 12, No. 29, pp. 46-52, 2017.

[14] M. S. Matias, M. M. da Silva, P. Ferreira and E. Ramalho, "A geophysical and hydrogeological study of aquifers contamina-tion by a landfill", Journal of Applied Geophysics, Vol. 32, No. 2-3, pp. 155-162, 1994.

[15] A. M. Abudeif, "Integrated electrical tomography and hydro-chemical analysis for environmental assessment of El-Dair waste disposal site, west of Sohag city, Egypt", Environmental Earth Sciences, Vol. 74, No. 7, pp. 58595874, 2015.

[16] G. Bhalla, A. Kumar and A. Bansal, "Assessment of groundwater pollution near municipal solid waste landfill", Asian Journal of Water, Environment and Pollution, Vol. 8, No. 1, pp. 41-51, 2011.

[17] P. V. Sharma, Environmental and engineering geophysics. Cambridge University press 1997.

[18] M. A. Rosli, Z. Daud, H. Awang, N. A. Ab Aziz, M. B. Ridzuan, M. H. Abubakar and H. A. Tajarudin, "Adsorption Efficiency and Isotherms of COD and Color Using Limestone and Zeolite Adsorbents", International Journal of Integrated Engineering, Vol. 10, No. 8, pp. 8-13, 2018.

[19] H. Alvarez-Vazquez, B. Jefferson and S. J. Judd, "Membrane bioreactors vs conventional biological treatment of landfill leachate: a brief review", Journal of Chemical Technology Bio-technology: International Research in Process, Environmental Clean Technology, Vol. 79, No. 10, pp. 10431049, 2004.
[20] W. Li, Q. Zhou and T. Hua, "Removal of organic matter from landfill leachate by advanced oxidation processes: a review", International Journal of Chemical Engineering, Vol. 2010, 2010.

[21] H. Weigand, J. Fripan, I. Przybilla and C. Marb, "Composition and contaminant loads of household waste in Bavaria, Germany: Investigating effects of settlement structure and waste management practice", In Proc. of the 9th International Waste Man-agement and Landfill Symposium, Cagliari, 2003.

[22] H. I. Abdel-Shafy, M. S. Mansour, "Solid waste issue: Sources, composition, disposal, recycling, and valorization", Egyptian journal of petroleum, Vol. 27, No. 4, pp. 12751290, 2018.

[23] M. I. Al-Wabel, W. S. Al Yehya, A. S. Al-Farraj and S. E. El-Maghraby, "Characteristics of landfill leachates and bio-solids of municipal solid waste (MSW) in Riyadh City, Saudi Arabia", Journal of the Saudi Society of Agricultural Sciences, Vol. 10, No. 2, pp. 65-70, 2011.

[24] O. K. Ouda, H. M. Cekirge, "Roadmap for development of waste-to energy facility in Saudi Arabia", American Journal of Environmental Engineering, Vol. 3, No. 6, pp. 267-272, 2013.

[25] Intergovernmental Panel on Climate Change, the supplementary report to the IPCC scientific assessment. Cambridge: Cam-bridge University Press, 1992.

[26] S. Chun, Sanitary Landfills: Toward Sustainable Development. Lund University, 2001.

[27] World Health Organisation, Air quality guidelines for Europe. Copenhagen, Denmark, 1987.

[28] M. Sundaravadivel, S. Vigneswaran and J. A. Doeleman, "Waste management in semi-urban areas of India: appropriate techno-logical strategies to overcome financial barriers", Environmental engineering and policy, Vol. 2, No. 2, pp. 91104, 1999.

[29] M. O. Saeed, M. N. Hassan, and M. A. Mujeebu, "Assessment of municipal solid waste generation and recyclable materials potential in Kuala Lumpur, Malaysia", Waste management, Vol. 29, No.7, 2209-2213, 2009.

[30] B. Johnson, Zero waste home: The ultimate guide to simplifying your life by reducing your waste, Simon and Schuster, 2013.

[31] APHA. Standard Methods for the Examination of Water and Wastewater. American Public Health Association, Washington DC, 2012.

[32] M. Aopreeya, C. Arunlertaree, C. Yuwaree, R. Boonprasert and R. Hutacharoen, "Blood cockle shell: an agro-waste for $\mathrm{N}$ and $\mathrm{P}$ removal of shrimp farm effluent", Environment and Natural Re-sources Journal, Vol. 11, No. 1, pp. 58-69, 2013.

[33] H. A. Aziz, A. Mojiri, and Wastewater engineering: Advanced wastewater treatment systems. IJSR Publications, Penang Malaysia, pp. 1-225, 2014.

[34] A. K. Aeslina, A. B. A. Mohd Mustafa, A. V. Sandu, M. N. Norazian, A. L. Alia Lisanah and H. Kamarudin, "Usage of palm shell activated carbon to treat landfill leachate", International Journal of Conservation Science, Vol. 5, No. 1, pp. 117-126, 2014.

[35] K. Y. Foo, B. H. Hameed, "An overview of landfill leachate treatment via activated carbon adsorption process", Journal of hazardous materials, Vol. 171, No. 1-3, pp. 54-60, 2009.

[36] Z. Daud, N. F. M. Hanafi, H. Awang, "Optimization of COD and Colour Removal from Landfill Leachate by Electro-Fenton Method", Australian Journal of Basic and Applied Sciences, Vol. 7, No. 8, pp. 263-268, 2013. 
[37] N. F. B. M. Hanafi, "Landfill Leachate Treatment by Combination of Electro Fenton and Sequencing Batch Reactor Method." PhD Dissertation, Faculty of Civil Eng., and Built Environ-ment, Universiti Tun Hussein Onn Malaysia., 2015.

[38] G. Tchobanoglous, H. Theisen and S. Vigil, "Integrated solid waste management: Engineering principles and management lssues," McGraw-Hill, 1993.

[39] B. Adhikari, S. N. Khanal, "Qualitative study of landfill leachate from different ages of landfill sites of various countries including Nepal", Journal of Environmental Science, Toxicology and Food Technology, Vol. 9, No. 1, pp. 23192399, 2015.

[40] S. Renou, J. G. Givaudan, S. Poulain, F. Dirassouyan and P. Moulin, "Landfill leachate treatment: review and opportunity", Journal of hazardous materials, Vol. 150, No. 3, pp. 468-493, 2008. 